\title{
Raising a true socialist individual: Yugoslav psychoanalysis and the creation of democratic Marxist citizens
}

Ana Antic

University of Exeter

A.Antic@exeter.ac.uk

\begin{abstract}
This article explores the surprisingly successful development of psychoanalysis in socialist Yugoslavia, and the discipline's relationship with both Western paradigms and Yugoslavia's own theory of workers' self-management. The article focuses primarily on child psychotherapy and psychoanalysis, and their attempts at reforming traditional Balkan 'authoritarian' families and helping raise democratic Marxist citizens. It argues that Yugoslav psychiatrists and psychoanalysts developed their own version of revolutionary and activist psychoanalysis, which was meant to contribute to a broad political and cultural discussion in Yugoslavia about constructing a society based on genuine Marxist collective and individual emancipation, an alternative to both Stalinist state socialism and Western capitalism/liberal democracy. Many psychiatrists, psychotherapists and psychoanalysts used overtly political language to frame their professional aims and experiences, and turned their consulting rooms into revolutionary sites. West European practices and theories of child psychoanalysis and psychotherapy figured prominently in Yugoslav clinical discussions and practice, but they were regularly linked to the broader goals of Marxist revolutionary politics, workers' selfmanagement or socialist struggle against patriarchy or 'bureaucratised' political relations. For that reason, the Yugoslav experiment, in which a new activist psychoanalysis became mainstream and state-funded psychotherapy, remains central to understanding the role of psychoanalysis as a tool for socio-political critique and activism in the second half of the twentieth century.
\end{abstract}

KEYWORDS: Psychoanalysis; Yugoslavia; workers' self-management; socialism; Praxis; Marxism 
In 1948, Vojin Matić, who would go on to become Yugoslavia's first trained child psychiatrist and the most important post-war psychoanalyst, was still a confused recent neuropsychiatry graduate, employed at Belgrade's Neuropsychiatric Clinic under the supervision of - and in perennial conflict with - leading neurologist Vladimir Vujić. According to Matić's own memories, this was a difficult period for a young professional who was uncomfortable with the dogmatic tenets of Yugoslavia's Sovietising psychiatry, as well as with the theories and therapeutic strategies of Central European organic psychiatry, which both insisted on neurological and physiological foundations of the human psyche:

It was universally accepted that everything is inherited, according to the rules of genetics, which was still in its infancy as a science and often abused, sometimes unconsciously by physicians themselves, at other times by politicians, who saw it as a political tool against their opponents.

In the context of building a new socialist psychiatry under the Soviet auspices, Matic felt obliged to constantly perform a 'magician's trick' of 'grafting human mental life onto what physiologist Pavlov ascertained in relation to dogs' stomach glands, that is. the so-called conditional reflexes', and to invoke biologists Oparin and Lysenko regularly in psychiatric discussions at the clinic. Moreover, the everyday realities of hospital work frustrated him, and he was particularly bothered by his neurologist colleagues' casually derogatory attitude towards psychiatric patients, who were not considered human and were not to expect a humane treatment: 'provoking and mocking [mental hospital patients] was often justified and viewed as a successful joke,' especially if they suffered from paranoia or were undereducated. ${ }^{1}$

Matić started his medical studies in 1930s Vienna with Julius Wagner-Jauregg, but the Viennese academic and intellectual setting was additionally important for Matić's 
professional development because this was where he first enountered and grew interested in psychoanalysis. In 1937, following his return to Yugoslavia, he started his psychoanalytic training in Belgrade and joined Nikola Šugar's psychoanalytic society. Unfortunately, the outbreak of the war interrupted Matić's psychoanalytic involvement, and in the immediate postwar years it seemed unlikely that he would be able to pursue his former interests in Freud, hypnosis and the concept of the unconscious. In the summer of 1948, he was scheduled to go to an unspecified clinic in Leningrad for a neuropsychiatric specialization. However, by mid-1948, that prospect was rendered impossible due to the dire political relationship between Russia and Yugoslavia. Instead, when, in that same year, a World Health Organisation (WHO) representative visited the Yugoslav Ministry of Health and asked interested young physicians to apply for fellowships to pursue medical specialisations in Western Europe, Matić submitted an application for Georges Heuyer's clinic in Paris, outlining his intention to work on child psychiatry. The application was soon approved and Matić received WHO funding to travel to Paris the following year. ${ }^{2}$ At Heuyer's clinic, Matić completed his habilitation, developed a lifelong interest in child psychoanalysis and made contacts which would determine his own career as well as the development of child psychiatry in Yugoslavia. Matić, a member of Šugar's prewar kruzhok, educated an entire postwar generation of psychoanalysts (and child psychiatrists) in Yugoslavia, and maintained close professional relationships with leading French psychoanalysts such as Rene Deatkine and Serge Lebovici. In the 1950s and 1960s, Yugoslavia became an experimental site for some of the newest and most progressive forms of child psychotherapy, while many of Matić's students and younger colleagues subsequently developed rich contacts with not only French but also British, American, and Scandinavian as well as Soviet psychiatrists and psychoanalysts. $^{3}$ 
The turbulent professional trajectory of Vojin Matić - and in particular his sharp change of direction away from Sovietised mental health frameworks towards psychodynamic and explicitly psychoanalytic theory and practice - was thus paradigmatic of the complex cultural and political influences to which Yugoslav psychiatry was subject at this time. Yugoslavia was the only socialist country in which psychoanalysis positively thrived and, despite a rocky start, developed into the dominant theoretical and clinical approach. ${ }^{4}$ Moreover, while Yugoslav psychiatrists and psychoanalysts quickly became well integrated in West European and American medical and professional networks, they still worked in an uncompromisingly socialist country which searched for an alternative form of Communist democracy. Therefore, the 'Westernisation' of Yugoslav psychiatry and psychoanalysis was a complex and layered process, and Matić and his many colleagues and disciples often reframed the concepts and techniques of British and French psychoanalysis to respond to the pressing social and cultural problems of building democratic socialism. This article will explore how West European psychoanalytic experiences and insights were used to help raise Marxist children and construct proper Marxist families in Yugoslavia, and how Yugoslav child psychoanalysts hoped to employ a psychoanalytic approach both inside and outside the clinic to revolutionise patriarchal, authoritarian and hierarchical social relations. This was then to be a revolutionary and activist psychoanalysis, which was meant to contribute to a broad political and cultural discussion in Yugoslavia about constructing a society based on genuine Marxist collective and individual emancipation, an alternative to both Stalinist state socialism and Western capitalism/liberal democracy.

This was truly unique: while psychoanalysis was far from banned and exterminated in socialist Eastern Europe, in most countries it was confined to various degrees of underground existence, and informally integrated in a series of therapies and approaches labelled as 'dynamic' or 'psychotherapeutic'.5 Moreover, both psychology and psychiatry played an 
important role in the project of producing a new, socialist personality across the region, but, as Christine Leuenberger pointed out with regard to the German Democratic Republic (GDR), in such circumstances psychoanalysis was more likely to be perceived as 'politically subversive' and to '[offer] an alternative conception of human nature' to the one promoted by orthodox Marxism-Leninism or Pavlovian approaches. ${ }^{6}$ It was arguably only in Yugoslavia that the clinical and theoretical aims of psychoanalysis aligned quite closely with the political revolutionary agenda of workers' self-management, so that psychoanalysis became directly involved in the process of overhauling the social and psychological conditions in order to build a democratic socialist person.

In this sense, the article contributes to the growing literature on cultural and professional contacts and exchanges across the Iron Curtain by focusing on the rather peculiar case of Yugoslavia, whose specific geopolitical and ideological position in Cold War Europe shaped its international involvement. Because of the country's search for an alternative Marxist system, the Yugoslav brand of East-West psychoanalysis bred a truly unique intellectual framework, which borrowed from a variety of psychoanalytic and political schools of thought in order to think through a set of original political and ideological dilemmas regarding the relationship between individuals and social structures. ${ }^{7}$

In her recent book on post-Second World War psychoanalysis, Dagmar Herzog argues that the post-war period was marked by an exceptionally close relationship between psychoanalysis and politics, and that, more than being simply an influential clinical technique or 'therapeutic modality', Western psychoanalysis of the 1960s, 1970s and 1980s evolved into a very prominent 'toolbox for cultural criticism', and ultimately deeply affected a variety of other political, cultural and intellectual fields. Herzog traces the trajectory of psychoanalytic controversial involvements in non-medical areas of life, and documents its development into an 'integral part of twentieth-century social and intellectual history' ${ }^{8}$ This 
willingness on the part of leading Western psychoanalysts to engage with broader social, religious and political issues, claims Herzog, enabled the discipline to experience its second 'golden age' in the 1960s, following its gradual decline in the United States of America (USA). In fact, these later psychoanalytic practitioners openly defied the early post-war injunctions of some of the most senior psychoanalysts to refrain from discussing any extrapsychological factors and stay away from political or sociological conceptions. Indeed, while Herzog's argument is convincing and very useful for re-framing the study of Cold War psychoanalysis, it remains one-sided in its almost exclusively Western focus. However, as this article aims to demonstrate, it was in a small socialist East European country that some of the most radical ideas regarding an activist psychoanalysis developed as early as the late1950s, well before comparable developments, described by Herzog, ensued in Western Europe. Moreover, Yugoslav psychoanalysts styled themselves not only as perceptive social critics and politically subversive intellectuals, but also as direct revolutionaries in their everyday clinical practice. Even though they participated in broader social and political discussions, their primary field of political action and involvement was the consulting room, in which they proposed to transform archaic social relations directly and promote selfmanagement by undoing traditional Yugoslav patriarchal and authoritarian families. In his commentary on Marxist psychoanalyst Igor Caruso's work, prominent Yugoslav psychiatrist Vladimir Jakovljević put forward the concept of 'engaged psychoanalysis', and treated it as identical - or at least highly comparable - to revolutionary Marxism in its emancipatory potential: 'Just like revolutionary Marxist praxis, engaged psychoanalytic practice aims to help individuals become freer creators of their own and social history, shedding light on the conditions and forms of their alienation and on possibilities for overcoming it. ${ }^{9}$ According to Jakovljević, it was a natural mission of psychoanalysis - in its 'anthropological' and activist guise - to play a central role in developing authentic personalities and deepening their 
consciousness: the discipline's potentials for constructing such authentic citizens and a free society were virtually unlimited, and this form of Marxist and anthropologically minded psychoanalysis was indispensable for achieving socialist revolution on both personal and societal levels.

In socialist Yugoslavia, therefore, psychiatry and psychotherapy opened up and became directly engaged in discussing crucial questions about shaping and reshaping political minds, experimenting with new political ideas, and building, as the Communist Party called it, a genuine democracy. Psychoanalytic and psychotherapeutic theories became increasingly important for understanding and developing the notions of individual enlightenment and selfmanagement that underpinned Yugoslavia's reform Communism. In turn, various philosophical and sociological interpretations of self-management shaped the Yugoslav, Marxist version of psychoanalysis and encouraged its practitioners to think in more activist and politically engaged terms.

\section{Raising self-managing Marxists: child psychiatry and the pursuit of freedom}

After 1949 the Yugoslav political system saw itself almost exclusively as an ideological antithesis to the Union of Soviet Socialist Republics (USSR), a 'really existing negation of the concept of state socialism' and central planning. ${ }^{10}$ It began searching for an alternative ideological and political basis for legitimation, which would move away from Stalinist totalitarianism without endangering the socialist essence of the Yugoslav revolution. In 1949, the Communist Party's leading ideologue and Yugoslavia's Deputy Prime Minister Edvard Kardelj suggested that socialism meant 'such an organization of a people's community which would represent a mutual cooperation of equal, free people' and would eliminate 'a uniformity imposed from above and hierarchical subordination to the centre'. ${ }^{11}$ Already by the early 
1950s, the most important ideologues of Yugoslav Communism developed their doctrine of socialist workers' self-management, which was partly based on Engels's notion of the 'state that withers away', on Marx's early writings and analysis of the Paris Commune, and on Gramsci's theories and partly inspired by the Yugoslav Communists' wartime experiences of popularly elected and popularly responsible committees/councils. The state soon implemented a set of legislative measures aimed at economic and political decentralization and 'de-bureaucratization' through workers' councils and gradual democratization of cultural and social life. Such reforms, of course, stopped well short of introducing a multiparty political system and disbanding the political monopoly of the Communist Party, but they did de-Bolshevize Yugoslav socialism and ultimately helped build a more pluralistic society. The political image of an ideal citizen of this novel and experimental system, consequently, changed quite significantly. The new Yugoslav self-managing worker needed to possess robust assertiveness, independence of mind and a host of other critical psychological and intellectual qualities in order to sustain the political experiment; he or she would also need to leave behind dogmatic, authoritarian or subservient frames of mind which characterised previous models of social relations. The emergence of such a revolutionary personality was going to be an exceptionally complex and difficult process, and the budding and ambitious psychiatric and psychotherapeutic professions in Yugoslavia wholeheartedly offered to take active part in this fundamental political project.

When Yugoslavia began forging closer political, social and cultural relations with Western Europe and the USA, it was psychiatry, psychotherapy and psychoanalysis in particular which profited the most from this exchange, and these professions became thoroughly Westernized and firmly integrated in these alternative networks. ${ }^{12}$ In the course of this transformation of the Yugoslav mental health professions, psychiatrists and psychoanalysts became primarily concerned with the issue of authoritarian family relations, 
aiming to liberalize and democratize society through democratizing family. ${ }^{13}$ In fact, Yugoslavia offered an excellent site for social experimentation in this regard: through the combination of the country's more open version of socialism and Western psychoanalysis, psychoanalysts hoped to achieve a more humane society, neither capitalist nor Stalinist, a society deeply committed to human emancipation and autonomy which invoked early Marx as its ideological beacon. That sort of self-realization of the individual was to be achieved only in a self-managing society - in which truly free, authentic, diversely educated workers and citizens took part in making all important decisions regarding their political, social, economic, cultural lives. ${ }^{14}$ In other words, Yugoslav 'psy' professionals wanted to create a society devoid of hierarchies, patriarchy and social and political authoritarianism. A combination of psychoanalytic psychotherapy and self-managing socialism was the key, and the experience of psychoanalytic treatment as well as the political conditions of antiauthoritarian self-management were supposed to transform the 'primitive' and dictatorial Yugoslav psyche. While Yugoslavia's most well-known political dissidents, philosophers and sociologists who gathered around the group Praxis complained that workers' selfmanagement failed to reach its full potential, psychoanalysts made that very same point, but were never persecuted. In that sense, self-management remained the mark of originality of Yugoslav psychiatry and psychoanalysis - it provided the basis on which the post-war psychiatric understandings of the human psyche and its possible transformation rested.

Child psychiatrists and psychoanalysts in Yugoslavia were particularly concerned with the great demands of modernity and of the new democracy in Yugoslavia, which asked for growing personal responsibilities and exceptional mental stamina. As the leading child psychoanalyst Matić, for instance, articulated a very telling understanding of the nature of socialism and the role of individuals in a socialist society. He conjured up a memorable 
image of experimental direct democracy and emphasized the supreme role of psychiatry in preparing the population for it:

We are entering a society in which every individual carries his share of responsibility, in which awareness, pleasure derived from labour, and true personal dedication are more necessary than ever, in which every individual will make decisions about economic, foreign, internal policies, about war and peace. In such a society, every individual should be raised in such a way as to be able to be involved in a community without fear or aggression, keeping the originality of his personality and feeling of personal freedom. ${ }^{15}$

This utopian vision drew directly on Marx's 'German ideology', which also served as the ideological foundation of the new platform of workers' self-management, and it can be compared to Kardelj's contemporaneous injunction that socialist Yugoslavia should 'constitute a free and courageous man whose worldviews and concepts were broad and diverse, and who was foreign to bureaucratism and narrow formalism of thinking. ${ }^{16}$

Indeed, in socialist Yugoslavia the issue of massive social and individual restructuring was high up on the political agenda. In particular, it was the elimination of patriarchal families that was to be at the core of the social revolution and of achieving the true emancipation of self-managing socialism. This patriarchal psychodynamics generated the authoritarian father, obedient and inconsequential mother, and highly hierarchical, disciplinarian relationships with children. Socialism, on the other hand, was to bring about the emancipation (political, social, personal) of women, and to introduce egalitarianism in family relations. However, in Yugoslavia the entrenchment of traditional family authoritarianism belied the achievement of such lofty democratizing aims within families, and it also fatally harmed the process of raising self-managing citizens. Moreover, if the 
Yugoslav psychiatrists looked east, they could see a very traditional and authoritarian, custodial psychiatry, which could not provide any meaningful guidance when it came to reeducating parents. Paradoxically, it was in the Western psychoanalytic and psychiatric ideas that the Yugoslav child psychiatrists discovered a set of guidelines for eliminating Yugoslav family and children pathologies, and for creating a more humane version of socialism. It was, in particular, psychoanalysis which was to become the intellectual tool for making families and parent-children relationships more socialist and more self-managing: in the 1950s and 1960s Yugoslav child psychiatric circles, psychoanalysis was seen as 'a democratic, liberating psychotherapy, which stands for independence and personal liberties of individuals'. ${ }^{17}$ As psychotherapist Vladeta Jerotić later confirmed, psychoanalysis coupled with self-analysis presented a unique way to achieving unsurpassed human autonomy, selfactualization and educational growth: unlike traditional psychiatry, it educated without relying on authoritarianism, and, by increasing patients' self-knowledge, 'created preconditions for the constitution of a mature and autonomous personality' and for attaining the 'freedom of self-development'. For Jerotić, the ethics of psychoanalysis required that practitioners shun any attempts at manipulation or indoctrination, and focus on advancing a democratic dialogue with the patient. ${ }^{18}$ For these reasons, a society of true socialist selfmanaging workers was in fact impossible without psychoanalytic guidance. As Jerotić elaborated in the discussion following his presentation, 'psychoanalysis needed to be accepted ... in a broader sense' in Yugoslav society, as it provided methods and strategies not only for dealing with mental pathologies but also for 'widening the consciousness'.

As we already saw in the case of Jakovljević, Yugoslav psychoanalysts and psychiatrists tended to draw direct parallels between psychoanalysis and Marxist revolution, and even between Freud and Marx themselves, as personalities who intervened in modern history in comparably forceful ways. In an extremely laudatory article about Freud's legacy, 
on the occasion of the 120th anniversary of his birth, Zagreb-based therapist Muradif Kulenović focused on the intellectual kinship of Freud and Marx, two exceptional thinkers linked by their fate as émigrés in London whose subversive ideas remain in equal measure dangerous and fascinating to contemporary audiences. Moreover, in Kulenović's reading, both Freud and Marx contributed to the same revolutionary historical project: of courageously 'shaking up the world of human illusions', and striving relentlessly to induce humanity to understand 'the deepest, the unknown in itself, that which had always been repressed, and which served to create mythologies or to be rationalised with notions and ideas far removed from people's genuine desires' ${ }^{19}$ Both Marx and Freud, the ultimate believers in Reason as a substitute for God, drew attention to core conflicts and struggles: between the conscious and the unconscious in the case of Freud, and between different social structures in a historical process in the case of Marx. In that sense, Freud's theory was in fact for Kulenović a conversion of Marx's interpretation of historical conflicts in the context of a society to the sphere of individual psychology, while Freud's Interpretation of Dreams was a continuation of sorts of The Communist Manifesto, coming exactly 50 years later. They both insisted on self-knowledge and the discovery of unconscious yearnings before any social and psychological liberation or revolution could be achieved. In this way, psychoanalysis yet again became a tool for Marxist praxis in the sphere of individual consciousness, which Yugoslav mental health specialists seemed to embrace wholeheartedly as much for therapeutic as for political reasons.

In addition, other Yugoslav psychiatrists emphasised that the discipline of psychoanalysis was particularly significant precisely because it allowed them to move away from the reductive organicism of traditional psychiatry, and to take into consideration systematically and analytically - the role of sociological, cultural and political factors in their patients' personal histories. For Marxist practitioners, as Stjepan Betlheim pointed out, this 
was of utmost ideological as well as clinical importance: a psychiatric framework which reduced psychological conflicts to biological, chemical or neurological explanations removed any potential for social critique or engagement, and undermined Marxist psychiatrists' ability to relate their work to broader socio-political trends and objectives. ${ }^{20}$ Psychoanalysis, as practiced in socialist Yugoslavia, made such a link eminently possible.

\section{Stamping out the authoritarian family}

A comprehensive transformation of family relations and structures was officially high on the list of priorities of most socialist regimes in Eastern Europe: at least in their formal legislative activities and public political campaigns, the people's democracies sought to involve women in the labour force in order to undermine the reactionary patriarchal attitudes, relations and practices which predominated within family settings. ${ }^{21}$ The socialist regimes' actual record in this regard was, of course, very chequered, and their support for women's emancipation at home and in the workplace was not always consistent or even entirely genuine. ${ }^{22}$ Still, in socialist Eastern Europe - and in Yugoslavia - the equality of women in the private and public spheres was fully legalised, and their access to universal (and free) education and healthcare significantly affected their social position, self-perception, and, at times, even their role within the family. These massive social and economic changes 'offered opportunities for educational and occupational advancement, cultural and material enrichment, and social engagement'; for many, the new socialist public discourses of equality and related policies also meant that new concepts of womanhood, motherhood and fatherhood suddenly became available. ${ }^{23}$ With regard to family structures, however, the socialist policies of emancipation and 'liberation' of women and families often led to the 'double burden' issue, and the formal and legal changes could not fully challenge the persistence of patriarchal mind-sets, so that 
socialist families frequently remained hybrids of progressive and traditional beliefs, arrangements and practices - a problem compounded by a dizzying pace of urbanisation and a large influx of rural population which brought its own family mores to socialist cities. ${ }^{24}$ It was precisely this problem of a slow and painful transformation of socialist family relations that Yugoslav psychoanalysts attempted to address in their clinical practice. In this regard, this clinical aim was fully aligned with the state's official political, ideological and legal commitments.

The Yugoslav version of socialism, moreover, seemed to dictate an extraordinary set of criteria for child-rearing, and the 1948 split played an enormous role in transforming the state's understanding of childhood and its core characteristics. Already in 1949, Milovan Djilas, one of the Communist Party's leading ideologues, instructed the existing children's organisations in Yugoslavia to avoid raising children 'whose minds will be cropped [and moulded] in the same way', but instead called on them to encourage the creation of 'free, socialist people, people who think and work courageously and fearlessly, whose opinions are broad and diverse' ${ }^{25}$ Furthermore, the socialist youth association of Croatia proclaimed a year later that children should grow up as 'decisive, intrepid, enterprising'. The Third Plenum of the Communist Party of Yugoslavia, dedicated to discussing the tasks of socialist education, fully supported Djilas's condemnation of schools which excelled at instilling 'uniform thinking', and throughout the 1950s Party documents insisted that the creation of 'free creative personalities' was the core aim of Yugoslavia's policies on children. In addition to rigid, traditional schools, patriarchal families presented a fundamental obstacle to the fulfilment of such ambitions.

The state's new thinking about childhood undermined patriarchal assumptions in yet another crucial way: it expected children to assume serious political roles and responsibilities from a very early age. Already at seven, by joining the Pioneer Organisation, socialist 
children exited the period of 'political innocence' or 'neutrality', and began the process of becoming ideological and political agents in their own right. ${ }^{26}$ Instead of seeing children as passive, deferential, politically oblivious and dependent - as they were socialised to be in authoritarian and traditional families - the socialist state viewed them as the future pillars and protectors of the legacy of communism, and active, conscious and equal contributors to the political process.

The new socialist family in Yugoslavia was supposed to raise future self-managers and liberated workers - and it had the greatest responsibility in effecting this grand transformation of psychological consciousness and social practice. As one treatise argued in the 1950s, the family remained the first school of human emotions and of new, revolutionary social relations, which prepared both children and parents for their new social and productive roles, and which therefore had to rest on the ideals of independence and lack of exploitation. ${ }^{27}$ Moreover, distinguished anthropologist and sociologist Zagorka Pešić argued that patriarchal morality prevented people from becoming active participants in selfmanaging systems, because it discouraged initiative and control from the bottom, and produced personalities who tended to wait passively for orders and directions rather than taking the lead themselves. The current society in Yugoslavia demanded 'conscientious and well developed personalities who will be prepared to lead the process of societal transformation', and families could not raise such personalities if they insisted on patriarchal mores and fought against children's 'stubbornness' ${ }^{28}$

Throughout psychiatric discussions, patriarchy and authoritarianism were marked as the authentic cultural traits of the Yugoslav family (and social) structure, which set it apart in a broader international context. One of the central characteristics of the Yugoslav family structure was that: 
Expressions of disobedience and resistance to parents, teachers and other adults, especially if they were higher up on the hierarchical scale, were condemned and punished, while obedience and submissiveness were encouraged. Parents and adults were sacred beings who may not be called in question or disputed. ${ }^{29}$

In their quest to instil in their children blind obedience and subordination to higher authorities, patriarchal parents became guilty of producing automatons and weak personalities, who would only be capable of fulfilling other people's orders. Yet, on the contrary, the fledgling Yugoslav society of self-managers needed independent young people, 'who thought with their own heads. ${ }^{130}$ The dangers of family authoritarianism were well illustrated in a clinical case treated by Ksenija Kondić, a young psychologist at Belgrade's Consultancy for mental hygiene. Kondić treated a 10-year old girl, Gordana, who had persistent problems with enuresis although her family situation at first appeared stable and comfortable. Still, the psychologist soon noted that the relationship between the parents was fairly disturbed, but even more importantly, that the father's harsh treatment of the girl might be the core of the problem. According to Kondić's notes, the girl's mother confirmed that, unlike his gentle and open attitude towards their son, 'the father was very cold [to the patient], and rigidly stuck to the view that a female child was less important than the male one.' Moreover, 'he wouldn't let her play with other children because she belongs at home' as a girl. It was precisely this lack of concern for the patient's feelings, which was itself a result of an inflexible patriarchal world view, that produced timid, apprehensive children, unprepared for any autonomous decision-making. As Kondić concluded, the patient was growing up to be the perfect image of submission: 'she speaks softly, fairly fearfully, with her hands in her lap, often looking down.' She was obedient and 'never said a word more than she was asked'. Moreover, 'she moves exactly as she speaks - silently, she is barely audible, careful not to 
touch or move any object.' Most damningly, 'she never does anything before asking for permission first. ${ }^{31}$

Yugoslav child psychotherapists used explicitly political terms such as 'democratic' and 'undemocratic' families, and placed the idea of democratic family relations and their importance at the core of their professional ideology. In Matić's opinion 'a child who grew up in a democratic family acts in a free way, is not withdrawn, is normally cheerful. However, a child who grew up in a non-democratic family demonstrates in their social behaviour the exact opposite characteristics. ${ }^{32}$ For Klajn, who openly declared his allegiance to both Marxism and psychoanalysis, lingering patriarchal attitudes in non-democratic families contributed to 'the slowing down of societal progress' in the direction of workers' self-management, because patriarchal organisations as such were remnants of past historical structures, whose gradual disappearance was inevitable in socialist Yugoslavia. In order for the 'new world' to be realised and for all the social and cultural sacrifices made for it to pay off, the future Marxist society would need to ensure that democratic families are based on and promote comprehensive 'social welfare': 'general wellbeing, feeling of safety, freedom from fear' as well as 'social justice for all, decreasing primitivism, end of slavery to anachronistic traditions... full emancipation of women, ... [and] increased sense of personal responsibility'. ${ }^{33}$ Klajn, like many of his colleagues, referred to patriarchal or undemocratic families as 'primitive', and drew his readers' attention to the phenomenon of urbanisation, in which many rural inhabitants brought traditional family values to urban settings and potentially undermined the modernisation process in that realm. Instead, Klajn called for the 'newcomers' to 'accept the already achieved degree of family democratisation in [their new] environments, and use their expansive youthful energy to further encourage that environment to take more steps towards attaining a new quality of free and democratic family'. ${ }^{34}$ 
In everyday dealings with patients and their parents, Yugoslav psychiatrists constantly collected evidence for what they perceived as the need to reform the structure of traditional families. At the Institute for Neuropsychiatry of Children and Youth, for instance, a 13-yearold girl was treated whose mental state deteriorated dramatically after her parents moved in with the paternal grandparents. The psychologist in charge of this paradigmatic case related the severe decline of the quality of nuclear family life to this decision of the parents to live in an extended family, and highlighted the pernicious effects that older and more traditional family members might have on the child's mental health as well as on the overall relationship between the child and her parents. ${ }^{35}$ In an even more dramatic case, an eight-year-old boy was brought to see a therapist because he kept attempting to commit suicide. The boy lived with his parents and paternal grandparents, which seemed to reinforce a highly hierarchical family set-up: the mother was, according to the therapist, consistently patient with and submissive to her in-laws, their needs and demands, while at the same time being extremely harsh and intolerant towards the boy. In addition, the boy reportedly witnessed instances of family violence committed by the alcoholic grandfather. ${ }^{36}$ Regardless of whether the child became insecure or aggressive, problematic family relations robbed the society and state of valuable citizens. ${ }^{37}$ Authoritarian, traditional and non-democratic families thus constituted an immense political problem, and an obstacle on the path towards self-managing socialism. ${ }^{38}$ Child psychiatrist and psychotherapist Nevenka Tadić shared her conclusion that a family's insistence on 'well tried and traditional value systems leads children to conformism and to political, religious, social infertility. ${ }^{39}$

The problem of rigid parents was placed at the core of this heated discussion, especially the personality and pernicious psychological and political influence of authoritarian, harsh and perfectionist fathers, who could reportedly be responsible for enormous pathological personality changes in childhood, and pre-determine a child's 
problematic relationship with law and state. In fact, in the context of psychoanalytic criticisms of the patriarchal structure of the family, Yugoslav child psychotherapists tended to pay relatively more attention than their Western colleagues to the role of the father in the development of the child's personality and pathologies. While the figure of the father was generally theorised to a significantly lesser extent in European psychoanalytic circles, those psychoanalysts and psychotherapists concerned primarily with critiquing authoritarianism and patriarchal hierarchies seemed to focus on the role of the father to an exceptional degree, possibly because the father - more than any other family member - symbolised the undemocratic patriarchal social potential and power asymmetry within the family. The father was seen as the representative of a repressive society, carrier and implementer of its values. As Till Van Rahden has convincingly argued in the context of West Germany, the idea that democracy ultimately rested on egalitarian and anti-hierarchical family practices increasingly gained ground from the 1950s onwards. A broad range of intellectuals and other public figures insisted that 'patriarchal-authoritarian' understandings of fatherhood inhibited the development of democratic consciousness and fostered fascistic and militaristic political choices. ${ }^{40}$ For many in Central Europe, then, the concept of political power was tightly related to ideas of fatherhood and familial authority, and attempts to democratise the social and cultural practices of the national public inevitably involved the promotion of new models of family relations.

In various case studies, the personal as well as social and political consequences of an inadequate father were portrayed as potentially daunting. In 1975, for instance, two physicians from the psychiatric department of Belgrade's elite Dragisa Misović hospital discussed a young male student, whose identification with the father could have easily led to a 'psychotic dissolution of personality' and the patient's subsequent inability to become an autonomous being and take part in constructive social relationships. ${ }^{41}$ The father was 
described as a 'dominant-narcissist' type, who 'submitted and shaped the entire family according to his own needs', while the mother was weak, passive and rejected by the father. Moreover, the son idealised the father throughout his childhood, adolescence and early youth - stifling criticism of and dissatisfaction with various aspects of the father's behaviour. In the psychiatrists' opinion, this led to a 'pathological identification' with the father, which inevitably bred dependency and failure to develop as an autonomous social being. The patient testified that:

Iin order to describe my father, I'm actually describing myself, because he is constantly in contact with me, constantly watching my reactions. Sometimes I feel like going somewhere and experiencing something myself [on my own], because he is always present in everything. ${ }^{42}$

At other times, he confirmed that the 'son is his father's mirror', while the father himself appeared rather proud that his child had 'ninety-nine percent of his [the father's] traits' ${ }^{43}$ For the psychiatrists treating the younger man, this was a supremely dangerous situation, and one they perceived to have been systematically planned by the father, who was afraid to allow the child (especially son) to grow up, become a rival and usurp or undermine the father's position within the family. The relationship between the father and the son thus turned into a political battle for power and dominance, in which the father's sense of safety was severely shaken. As a result, the son of a dominant or narcissistic father would find it very difficult to avoid fully adopting and imitating the father's concepts and value systems, and to develop as an independent, confident and self-actualised person. Instead, the patient tended to behave almost exclusively according to the father's directions, judgments and evaluations. In a situation like this, the younger man proved inadequate in his adult roles as a husband and father, and as a political activist. In fact, the psychotherapeutic treatment seemed to directly encourage the patient's disobedience and challenges to the parental authority, and those were 
deemed as signs of recovery and progress. The psychiatrists reported that, towards the end of therapy, the patient's father came in to complain about his son's 'insolence' and disrespect, asking if he was allowed to beat him up. ${ }^{44}$ This dramatic change in behaviour, more than anything else, signalled to the psychiatrists a possibility that the patient might be able to recover the autonomy of his ego.

Some psychoanalysts took their discussions of the issue of patriarchal families beyond their consulting rooms and into the public realm. In the second half of the 1970s, for instance, Matić agreed to write an advice column for a high-circulation Belgrade-based popular magazine TV Novosti (TV News), and his unusual yet long-term engagement with thousands of readers' letters illustrated many of the themes which marked this peculiar development of Yugoslav psychoanalysis. In his responses to readers of all ages (very often children and teenagers), Matić described challenging familial relationships and their harmful effects on children in particular; such families were characterised by the 'parents' incomprehension, brusqueness and rigidity' which frequently resulted in their children's serious psychological disturbances and dysfunctionality. One reader blamed his personal difficulties on the 'narrowmindedness' of the society, in which 'a daughter does not dare approach her mother with her problems.' Certain problems reported to be typical for traditional patriarchal families often came to the fore, and the letters Matic chose to respond to publicly emphasised the gravity of psychological complications that such situations could cause in those families' most vulnerable members. As one reader stated, her inability to continue with school and her deep depression were due to the constant malicious arguments between her mother and paternal grandmother, who lived in the same household throughout her childhood. Another female reader complained of her sense of worthlessness and her inability to set up an independent life because her family's love and appreciation were always exclusively showered upon her brother, while her parents 'constantly silence[d] and [misunderstood]' her, and ignored her 
needs and desires. ${ }^{45}$ Parents who were unnecessarily or incessantly harsh and dismissive in their communication with children, and physically and verbally aggressive over the 'slightest of misdemeanours which for others would appear completely normal', paraded through Matić's column almost on a weekly basis. This may have been his conscious choice: in order to emphasise the social and political importance of 'democratic' and mutually respectful family relations, and thus the multiple and often irreversible negative consequences of everyday family brutality.

Matić, of course, regularly supported children and young people when they complained of their 'old-fashioned' families and their expectations, and encouraged them to resist or, if possible, move away from such pressures. In one instance a reader reported that the grandparents she was living with after her parents' divorce were extremely strict, only allowing her outside if escorted by her brother and constantly reprimanding her. She wrote that her 'grandfather, moreover, curses, screams at me, beats me',. In response, Matić noted with regret that 'old people' in general found it hard to alter themselves and their 'archaic views' but commended the reader for managing to resist such demands successfully and defend herself against them. ${ }^{46}$

\section{Activist psychoanalysis}

Emancipatory psychotherapy was by no means a socialist invention: left-wing groups across the world recognised its potential for aiding progressive political projects. In particular, the 1960s and 1970s demonstrated that psychological and psychotherapeutic theories and techniques could be mobilised for explicitly emancipatory political aims. For instance, while criticising the psychological profession's propensity to pathologise women's complaints and reinforce patriarchal authority as natural, American second-wave feminists utilised the 
language of humanistic psychology in order to push their own liberationist agenda, and to argue that women needed opportunities for personal growth, self-actualisation and for the development of 'their fullest human potential' ${ }^{47}$ Yet it was only in Yugoslavia that this radical political agenda of self-actualization through psychotherapy became the primary purpose of the profession as a whole. In the American and West European cases, feminist consciousness raising groups existed on the margins of the discipline, and tried very hard to distinguish themselves from conventional psychotherapy. Political activists often adopted (and radicalised) the language of psychology, psychotherapy and psychoanalysis, but it was only in socialist Yugoslavia that this became the profession's (and state-funded) mainstream identity.

However, in the second half of the twentieth century many worried that the strategy of forging an alliance between radical politics and psychotherapy carried the risk of depoliticising the women's liberation movement, and re-framing women's oppression as a personal, psychological problem with an individual 'solution' which precluded collective political action. ${ }^{48}$ The Western feminist movement never fully resolved this paradox. Yugoslav psychoanalysts, on the other hand, addressed this problem squarely from the very beginning, emphasising that the dividing line between family therapy and political revolution was porous and increasingly irrelevant, and using explicitly political language and concepts to talk about family relations, children's mental health and the role of the parents. In the Yugoslav case, the sustained state investment in such a revolutionary brand of psychotherapy produced a unique situation in which a radical political agenda dominated the discipline of psychoanalysis, while psychoanalysts saw direct links between family and political structures, turning the very therapeutic encounter into a vehicle of revolutionary politics.

Many of the Yugoslav child psychiatrists (especially those who underwent psychoanalytic training) proposed original ideas regarding an activist psychoanalysis, which 
might abandon its 'aristocratic' position in the cabinet and get involved in proper social change. They often criticised Western psychoanalysis for its failure to focus more on collective rather than individual freedoms, and to take detailed theoretical account of the numerous economic, political, racial or religious pressures in modern societies: 'the psychoanalyst... most frequently closes his eyes before the social and political issues of his time. ${ }^{49}$ What they had in mind for their profession was radically different, and it involved changing the society by revolutionizing family relationships and structures through clinical practice. Such an unusually activist stance might be one of the most defining features of East European (socialist) psychoanalysis, and it was founded on the ideas of self-management and its continuous implementation in both families and society at large. In her book on psychopathology and youth, Tadić drew a direct parallel between a 'patriarchal family' and 'bureaucratised social' relations, in fact equating non-democratic familial arrangements with dictatorial political structures, and concluding that the youth needed to liberate itself from both in order to realise its own authentic emotional, cognitive, social capacities. ${ }^{50}$ Family thus became yet another experimental site in which hierarchical relations were to be gradually unravelled and patients were to be induced to replace them with more egalitarian and selfmanaging structures. The psychotherapeutic process had immense repercussions for the reality outside the consulting room: the crucial experiences of liberation, free expression and decision-making, self-knowledge and increased consciousness which patients gained in the course of psychoanalysis would inevitably shape their actions and behaviour in everyday life.

For child psychoanalysts, it was particularly important from the very beginning of the therapeutic relationship to demonstrate their respect, authentic interest and curiosity, and pay painstaking attention to everything the patient said or did. The therapist thus assumed the role of a liberator and emancipator. The therapist, moreover, aimed to reduce the child's dependency on the parents, while an appreciation of the patient's opinion needed to be 
communicated and followed through consistently. Slovene analyst Meta Kramar noted that the 'therapist... enabled him [the adolescent patient] to become active in his own life and assume initiative, and above all to become autonomous in his decisions'. Moreover, the 'therapist's respect for the patient's autonomy should be even more firmly embedded in his relationship with the patient in child psychiatry, because the patient, as a child, was used to assuming a more passive and subordinated position before adults'. ${ }^{51}$ In fact, such psychoanalytic insights provided an excellent framework for political interventions; the therapist needed to help their young patients to 'fight for their true needs and independence', even if it meant encouraging children and adolescents not to accommodate to the demands of their - flawed - family environment.

Following the lead of Anna Freud, Franz Alexander and Virginia Axline, Tadić recommended that analysts and therapists behave as 'the good parent', correcting the mistakes of patriarchal child-raising, 'by accepting the [patient] exactly as they were, with their good and bad traits, by listening carefully and appreciating them without judging, devaluating and condemning them'. In this way, therapy could alter children's and young people's social potentials and abilities, and teach them to engage in social relations differently in the future. ${ }^{52}$ Moreover, the therapist must 'maintain deep respect towards the child's ability to resolve their own problems if they are given an opportunity for that'. Following Axline's principles of nondirective play therapy, Tadić advised that, in the complex relationship between the child patient and the therapist, 'the child leads, the therapist follows.' In this way, a full-blown personal transformation would be allowed to occur:

In the safety of the [therapeutic] room, where the child is the most important person, the master of the situation and of himself, where nobody tells him what to do, nobody criticises what he does, .... he feels at last that he can spread his wings. He can look at 
himself clearly as he is fully accepted. He can test his ideas, and express himself fully, because this is his world..$^{53}$

Importantly, while in Western Europe or the US such clinical experiences primarily aimed to advance individual transformation and emancipation of child patients, Yugoslavia therapists placed these personal psychological goals explicitly in a political context: the issue of human freedom and its relationship to authoritarianism came to the very centre of the psychiatric understanding of child and youth psychotherapy. Tadić used very peculiar terminology to describe the position of a child psychotherapist who was asked to treat a patient by parents or a state agency: 'a psychotherapist must be aware of a trap, in which they often fall, to become a protector and advocate of the interests of the family and of the society, and to serve their interests uncritically.' This was particularly important because it was most often the case that the decision regarding psychotherapy was not made by the patients themselves, but by their parents, schools, or psychological centres who 'should take responsibility for their part in the development of mental disturbances in children and youth'. Furthermore, sending a child to a therapist could be 'the last and most decisive pressure and enslavement'. Clinical contexts thus turned into arenas for political experimentation and activism: 'The therapist should not act like a person who offers freedom to the enslaved while smiling at and encouraging the enslaver,' but should instead increase the political awareness and liberation potential of the enslaved. ${ }^{54}$ Speaking of relationships inside the consulting room, Matić stated that 'a child, with his individuality, already attained the right of citizenship in medicine', and this attainment, a new realisation of the psychological essence of children's personalities, should now be the first step towards a transformed political subjectivity.

Although she did not directly refer to them, Tadić's critical proclamations about the role of psychiatry in perpetuating societal oppression echoed some of the most important principles of radical psychiatry, a contemporaneous and mainly Western-based movement 
which emphasised alienation, hierarchy, inequality and social coercion in modern societies as the core causes of mental suffering. As Claude Steiner, the movement's founder and one of its most prominent theorists, wrote in an influential 1971 article, '[p]sychiatry has a great deal to do with the deception of human beings about their oppression,' and it is precisely this collusion that Tadić's vision of activist psychoanalysis attempted to unravel: by proclaiming their 'neutrality', psychiatrists in fact became '[enforcers] of the domination and [their] lack of activity becomes essentially political and oppressive. ${ }^{55}$ On the other hand, radical psychiatrists, (as well as Tadić and her colleagues) primarily sought to counter the deception, make patients aware of their own oppression, and enact liberation through an explicitly politicised therapeutic process. Tadić and Matić appeared to closely follow Herbert Marcuse's injunction - that psychiatry should be a 'subversive undertaking' which would 'prepare the mental ground for [the struggle against society]', that any action to tackle psychological illness would need to take place on a political level, and that psychiatrists should act as political saboteurs of any oppressive elements within the social order, preventing their patients from '[collaborating] in their own repression'. ${ }^{56}$ As in the advice of the Massachusetts-based Radical Psychiatry collective, Tadić's writings invited her colleagues to see their (child) patients 'as oppressed people who must be liberated' rather than "sick people who [needed] "treatment". 57

In the case of some analysts, the critique of authoritarianism and suppression of children's vital creative capacities extended to the school system quite naturally. Tadić's close collaborator Svetomir Bojanin wrote of the contemporary schooling system as a 'social disease', which merely aimed to produce docile servants of the ruling political regime and actively prevented individual emancipation and 'liberation of the spirit'. 'Creatively frustrated people', argued Bojanin, 'were often able to lead only limited existence, experienced neurotic difficulties, became prone to alcoholism, drug abuse, and even schizophrenic psychoses. ${ }^{158}$ 
Yet in addition to these individual psychological problems, the schooling system as it was reportedly led to even greater political dangers. By encouraging obedience and competitiveness, schools undermined children's and young people's solidarity, empathy and independence of mind, and, in addition to producing mental disorders, made societies vulnerable to both 'the deathly promoters of fascism with their Mathausens, Jasenovacs and pogroms and the deathly promoters of Bolshevism with their Gulags and Goli Otoks' ${ }^{59}$ In other words, the third way of self-management and personal liberation was not possible without a radical re-thinking of the educational system and its rigid - psychopathological hierarchies, in which teachers were 'the absolute masters' in their classrooms.

\section{Psychoanalysis and political dissidents}

By the 1960s and 1970s, this radical discourse of freedom, creativity and individual selfrealisation spread beyond the psychoanalytic circles, and came to inspire the philosophy of those dissidents and critics of Yugoslav realities who emphasized the failures and insufficiencies of reform Communism. The political, social and economic reforms implemented after the 1948 conflict produced a fairly pluralistic society which was nevertheless vulnerable to authoritarian political turns and decisions of the Party and state elites. Yet this dynamic and changing society also bred new, highly politicized intellectual elites, who, encouraged by the reformist impulses of the 1960s, began to shed critical light on the actual achievements and applications of the self-managing system, and paid particular attention to the theme of individual freedoms, alienation, self-realisation and emancipation. In the 1960s and 1970s a number of distinguished intellectuals inspired by the 'new left', critical theory and Sartre's existentialism, formed a unique political dissident group - Praxis - which sharply criticized new forms of alienation and political hierarchies emerging in socialist and 
self-managing Yugoslavia. In the summer of 1968, Yugoslavia was also shaken by widespread student protests, which clamoured against the 'red bourgeoisie' and the degeneration of socialist self-management. ${ }^{60}$ These emerging critical discourses had a lot in common with, and were often stimulated by, the psychiatric and psychoanalytic writings on the creation of a free, liberated socialist individual. Indeed, the language of Europeanised child psychiatrists and psychoanalysts resembled the political symbolic and rhetoric of the Praxis group in particular.

The Praxis group mainly consisted of young sociologists, anthropologists and philosophers from the Universities of Belgrade and Zagreb, who opposed the orthodox Marxists' exclusive focus on the theories of surplus value and historical materialism, and proposed instead that the oft dismissed humanistic element was key to understanding Marx's philosophy. The Praxis project thus aimed to recuperate this humanist strand, and to re-define Marxism as the 'philosophy of man', centred around the notion of praxis as a 'universal, free, creative and self-creative activity', and a sole way for humans to achieve their full creative potential. Most importantly, Praxis intellectuals called for a persistent and permanent constructive critique of all the emerging socialist institutions in Yugoslavia, inviting citizens to reflect on 'the complex question of a suitable form of a social, economic and political system which would enable man with certain intrinsic potential to reach the highest level of self-realization and maximization of his (internal) creative potential' ${ }^{61}$ What they faced in the Yugoslav context was a rather under-developed peasant society, in the midst of a fast-paced industrialisation and urbanisation led by an authoritarian, top-down modernising Communist bureaucracy.

Importantly, Praxis discussions zoomed in on the failings and deficiencies of the Yugoslav self-managing system. As one of the group's most prominent members, Gajo Petrović, observed, even in those states 'where there are efforts to realize a genuinely human 
society, the inherited forms of inhumanity aren't defeated and deformations emerge that didn't exist earlier' ${ }^{62}$ In its internationally acclaimed journal and a series of very popular summer schools, Praxis was determined to define and analyse the social and political obstacles to this humanistic development in Yugoslavia. The key among such obstacles were the authoritarianism and hierarchical nature of the overly bureaucratised Yugoslav socialist state and Communist Party. For Praxis intellectuals, it was precisely those conditions that the new generation of child psychoanalysts identified as supremely pathogenic in the family context which could actually cripple human beings in a political sense and arrest their development as democratic citizens. These dissident Marxists emphasised the need to tear down the distinctions between state and civil society, and to replace the alienated conditions of bureaucratised socialism (rigid state and party structures) with self-managing institutions. In this process, the main enemy would be the mentality of obedience and absolute compliance to authorities, fostered in Yugoslavia's political culture according to Praxis, as well as in Yugoslav overly patriarchal families according to child psychoanalysts.

One of the most important - and lasting - legacies of the Praxis project was its exceptional international intellectual network of stellar collaborators, contributors and followers. Some of Europe's most prominent left-wing and critical theory intellectuals, such as Erich Fromm, Herbert Marcuse, Gyorgy Lukacs, Jurgen Habermas, Leszek Kolakowski, became regular contributors to Praxis's philosophical journal and participated in the increasingly internationally renowned Korčula summer school (1966-1974). Herbert Marcuse and Erich Fromm in particular became frequent guests of the Praxis project, with Marcuse playing an extremely important role in the summer school's ambitious theoretical and philosophical work. ${ }^{63}$ The intellectual profile of these reputed participants sheds some light on the role of psychoanalysis in Praxis' philosophical discussions: Marcuse's and Fromm's interest in the interrelationship between Marxism and psychoanalysis affected Praxis' own 
understanding of humanist Marxism to an important extent. Throughout the 1960s and 1970s, Yugoslav Praxis intellectuals debated the importance of Freud's philosophy for furthering the revolutionary project of European and Yugoslav socialism, and for Marxist liberation of the individual. In that sense, through Marcuse, Fromm and their Yugoslav followers, psychoanalysis remained one of the focal points of the new left in Yugoslavia. While this was often a divisive point, with critical voices questioning Freud's place alongside Marx, Hegel or Nietzsche in the pantheon of great European thinkers, Praxis intellectuals remained deeply interested in the potential of psychoanalysis to contribute to the development of a vision of a 'non-repressive civilisation', and to provide both psychological and philosophical guidance on the subject of revolutionising the stifling bourgeois society and overcoming alienation. ${ }^{64}$ In Praxis discussions, the notion of the ultimate liberation of human creative potentials in a free society rid of (political and psychological) repression was tied up with psychoanalytic ruminations. ${ }^{65}$ Consequently, there were close personal connections and overlaps between Praxis and the psychoanalytic profession - Nevenka Tadić and one of Praxis's most prominent philosophers Ljubomir Tadić were married to each other, for instance, and a number of intellectuals, such as Zagorka Pesić, Vladimir Jakovljević, and Nevenka Tadić, straddled the two camps, combining psychoanalytic, anthropological and sociological insights in their research. ${ }^{66}$

Moreover, as Branislav Jakovljević claims in his study of the effects of the theory of self-management on cultural and artistic practices, 'part of the reason Marcuse and other reformist Marxists kept coming to Korčula was that in Yugoslavia their ideas were not confined to street protests, but had at least some chance of filtering up to the highest levels of institutional politics. ${ }^{167}$ Among other things, the above-described activist psychoanalysis was one such direct link between intellectual work and high politics, and, along with the theories of alienation and self-management, constituted an 'avenue of this traffic between critical 
theory and state politics. ${ }^{168}$ Socialist Yugoslavia may have been the only country in Europe (and even the world) in which the liberation politics of psychoanalysis overcame the narrow confines and limited social impact of philosophical texts, and became everyday clinical practice, supported by the state's core political principles (and funding).

Reflecting on the relationship between the political turmoil of the 1960s and psychoanalysis, Matić echoed Praxis philosophers by criticising the Yugoslav society for its reported preservation of 'niches of coercion': in their own niche (and family was certainly one of them), everyone is allowed to terrorise their subordinates and to live his or her dictatorial potentials/fantasies while the supposedly self-managing society remains blind. In Matić's opinion, it was within families that violent societal structures needed to break first, in order for democratising tendencies to eliminate the psychological 'need for authority' and to enable the development of truly humanist Marxist individuals. ${ }^{69}$ Matic identified the family as the bastion of state violence, which carried 'the greatest potential for violence', and traditionally produced conformist citizens, loyal members of the community who would never seriously challenge the authorities: 'the parent, as an... educator in conformism, is the person on whom the state can always rely. ${ }^{, 70}$ Drawing heavily himself on Marcuse and Fromm, Matić criticised the current state of affairs, in which 'parents start practising violence from the very birth [of the child]', and primarily rely on fear in their child-raising practices. ${ }^{71}$

'Humanity was slowly recovering from state violence', Matić opined, as well as from 'moral masochism' and 'internal identification with the aggressor'. These were core personality traits which had made dictatorships and violent authoritarianisms possible, even necessary and supported by the population: 'Self-management is now starting to replace this identification with the aggressor, but many are still trying to abuse it, even unconsciously, to fulfil their lingering need for coercion.' Therefore, Matić offered self-management as a remedy of sorts for the pathologies of authoritarian personality. 
Just as psychoanalysts regularly used explicitly political references and metaphors, some Praxis intellectuals adopted the language of psychiatry, and child psychoanalysis in particular, to describe the goals and dangers of their vision of the path towards genuine socialism. University of Belgrade philosophy professor Ljubomir Tadić argued that any government's understanding of political power in exclusively Hobbesian terms constituted a veritable 'political pathology', and that this pathology was best expressed in the government's use of the concept of the 'masses', whose capacity for rational participation in public affairs was allegedly null. ${ }^{72}$ As argued above, it was precisely this type of multifaceted and universal political participation of all citizens that Matić had in mind when he advised parents of his patients on how to raise children. As another Praxis philosopher clarified, 'a society is socialist to the extent that it opens possibilities for the free creative development of every man. ${ }^{173}$ Ljubomir Tadić similarly argued for a system which would advance the 'coming of age' of its citizens, and reject 'paternalistic guardianship', which had no place in a true socialist democracy. ${ }^{74}$ Instead, Tadić claimed that any democratic Marxist society would need to respect the autonomy of public opinion, and combine the ideals of a true community (solidarity, empathy, dignity) with unrestricted individual freedoms. This insistence on the communal ideal of the Greek polis as the right social context for developing unalienated and fully realised Marxist individuals also figured prominently in psychiatric and psychoanalytic discussions of the time..$^{75}$

In her article on the problems of adolescence and family, Zagreb psychologist Martina Zmuc-Tomori described adolescents' interventions within their families in overtly political terms, which strongly resonated with the turbulent political developments of the $1960 \mathrm{~s}$ and 1970s in Yugoslavia. In fact, the adolescent was the revolutionary, someone who upset the hitherto predominant and settled value systems of the family, which Tomori argued was equivalent to a micro-society. Her article was published in 1974, when the conflict between 
the state and the Praxis group was coming to a head; in 1975, their journal was finally banned, while eight professors of the Belgrade University were forced to leave their positions. In this context, the language Tomori chose to analyse the complex relationships within families was highly reminiscent of the political discussions at hand. In the world of family psychoanalysis, it was in fact the rebellious and often repressed or harshly criticised adolescent who took up the social role played by Praxis - or the student protesters of 1968 in the broader context. Tomori claimed that:

If we look at the family as a whole...we will understand that [the adolescent] transforms its dynamic completely. The adolescent is the carrier of new values within that whole. He persistently attempts to re-shape the existing system of power and dominance, the system which had already been balanced and confirmed in a family with pre-adolescent children. ${ }^{76}$

Therefore, frequent conflicts between parents and their adolescent children were not only normal, but were also fully understandable in terms of political power sharing and negotiations. Moreover, one of the leading Slovene psychologists of the time Lev Milcinski argued that the adolescent's behaviour was bound to be much more shocking to the parents if they were 'firmly tied to the rigid patterns of the conventional society, and had already envisaged a place for their son or daughter in an institutionalised social structure'. ${ }^{77}$ In the same vein, one of the core sources of the adolescent's psychological conflicts was their disillusionment with their own parents, in whom they had once seen as near gods.

In much the same way, one could add, the Praxis group expressed their own disillusionment with the formerly unassailable heroes of socialism, including Tito himself, the ultimate father figure, but also Marx and Lenin, who could now be criticised and revised in Praxis's academic meetings and writings. The peculiar language and value systems of 
Yugoslavia's psychoanalysis thus ultimately came to be tightly intertwined with critical discourses of humanist Marxism. As Tomori concluded, adolescents 'woke their families up from their ideological dormancy and remind them of some of their long forgotten principles' - just as Praxis and the protesting students reminded Yugoslavia's official Communist ideologues of some clearly forgotten principles of early Marxist humanism and ideals of individual emancipation. Finally, 'the adolescent could take a lot away from the family, but could give a lot to it as well': a warning, perhaps, to the overly bureaucratized Yugoslav authorities to heed the voice of the rebels. ${ }^{78}$

\section{Conclusion}

In the second half of the twentieth century, radical and critical psychiatry became an extremely influential intellectual strand, inspiring philosophers, political thinkers and activists who critiqued and grappled with different forms of hierarchy, oppression and inequality. Street protesters in 1960s Western Europe relied on psychoanalytic theory to make sense of their environment and to frame their visions of a future society, while the intellectual 'new left' borrowed and adjusted psychoanalytic insights in order to analyse the socio-economic and cultural fault-lines of modern society. In most of these places, psychoanalysis was often the ultimate subversive discipline, aiding the intellectual process of deconstructing the existing political power structures. In Yugoslavia, however, as this article has sought to demonstrate, psychoanalysis became a tool for revolutionising society in line with the state's (official) political ideology. This did not mean that psychoanalysis was not in fact subversive in self-managing Yugoslavia. As we saw from their intellectual cross-overs with Praxis, the language of psychoanalysis could serve to criticise the failings and hypocrisies of Yugoslavia's political project. Yet the theory of workers' self-management and 
of alienation, as developed by Yugoslav Party ideologues, relied centrally on the ideas of human emancipation and full creative development, individual freedom and autonomy. In their sustained attempts to carve a political space for themselves between Stalinist orthodoxy and Western capitalism, Yugoslav Party Marxists provided an opportunity for psychoanalysts to expand on their visions of individual emancipation and revolutionary society. As it happened, the Yugoslav psychoanalysts' understanding of their own role in transforming traditional 'authoritarian' families aligned closely with the state's political project for tackling patriarchy, family relations and gender relations.

In their professional discussions and clinical publications, many psychoanalysts used overtly political language to discuss their professional aims and experiences, showing that the goals of Marxism, workers' self-management and psychoanalysis were fundamentally intertwined. Their involvement in the Western networks of knowledge production was central here. West European practices and theories of child psychoanalysis and psychotherapy figured prominently in Yugoslav clinical discussions, but they were regularly linked to the broader goals of Marxist revolutionary politics, workers' self-management or socialist struggle against patriarchy or 'bureaucratised' political relations. Yugoslav 'psy' professionals made a concerted effort to prove an ideological affinity between Marxism and psychoanalysis - Vladislav Klajn, Vojin Matić, Nevenka Tadić, Vladimir Jakovljević were some of the most prominent ones, and they debated the notion of activist psychoanalysis, which sought to get involved directly in the social and political overhauling. In most cases, the consulting room was a revolutionary field, in which broader social, cultural and political changes played out, and the project of transforming and democratising families was part and parcel of the more ambitious aim to develop a democratic Marxist personality and society. In that sense, the Yugoslav experiment, in which a new activist psychoanalysis became mainstream and state- 
funded psychotherapy, remains central to understanding the role of psychoanalysis as a tool for socio-political critique and activism in the second half of the twentieth century.

In Yugoslavia, the legacy of these extraordinary developments remains mixed. Following the breakdown of socialism, the psychoanalytic profession became both freer since it did not have to field occasional ideological attacks and prove the compatibility between Freud and Marxism - and more restricted in its reach - since state funding decreased dramatically and the era of free psychoanalysis came to an end. The state's political interest in psychoanalytic projects disappeared completely, together with any investment in the theory and practice of workers' self-management. The marginalisation of psychoanalysis on a global scale played an important role in these post-socialist developments. In this regard, postYugoslav psychoanalysis followed broader trends and grew increasingly side-lined in the context of mental health services, while biological psychiatry took centre stage. At the same time, however, the strong networks and theoretical advances achieved under socialism enabled post-socialist psychoanalysts from the Yugoslav territories to remain very prominent in the international circles: both the Croatian and Serbian psychoanalytic societies gained official membership of the International Psychoanalytic Association after 1991, and became among the most active and influential participants from Eastern Europe. Talented practitioners such as Tamara Popovic-Stajner, Aleksandar Vuco and Eduard Klain quickly rose to prominence in the international psychoanalytic institutions, and worked effectively on strengthening their respective national associations, and on promoting psychoanalysis in Eastern Europe. ${ }^{79}$ Their critique of traditional and authoritarian families, and of the pernicious effects of patriarchal relations on children's and women's mental health remained current and germane to the former socialist societies in transition, especially as those societies renounced some of the most progressive social and cultural policies of the previous era and opted for social conservatism, extreme nationalism and political authoritarianism in order to 
build ethnically clean nation-states. As one author termed it, post-Yugoslav psychoanalysis became a 'resistance movement' - a marginal and often subversive discipline, critiquing a number of prominent social and political trends. ${ }^{80}$ In that sense, with the death of Yugoslav socialism, post-Yugoslav psychoanalysis lost its unique link to a broader political project, but it still remained an important minority group within the mental health sector, which has played a vital role in treating (child) survivors of the wars of the Yugoslav secession, and engaged with the dire psychological consequences of the violent breakup of the country and its painful transition to neoliberal economy. ${ }^{81}$

Moreover, it is possible, as some authors have recently argued, that the legacy of workers' self-management affected to some degree the radical political movements and grass-roots initiatives of the 1990s and 2000s. Since 1991, the former Yugoslav territories have seen a number of anti-regime and anti-war protests, student movements, workers' demonstrations and other experiments in direct democracy, which have invited citizens to radically re-think their relationship to the post-socialist political authorities. In that sense, even though the post-Yugoslav political and economic elites quite universally dismissed the project of self-management, its principles, promoted in no small part by the psychoanalytic community, have continued to shape some important left-wing groups' and citizens' political experiences and to influence the face of the new left in the Balkans. ${ }^{82}$ 
${ }^{1}$ V. Matić, Moji zivoti (Novi Sad, 1985), 86-87.

2 Archive of Yugoslavia, Fond 31, Komitet za zastitu narodnog zdravlja, f. 65-92, 'Spisak lekara predloženih za specijalizaciju u inostranstvu'.

3 K. Kondić, 'Vojin Matić and Filozofski Fakultet', in Legende Beogradskog Univerziteta: Vojin Matić: 1911-1999 (Belgrade, 2008), 12.

${ }^{4}$ For an overview of the development of Yugoslav psychoanalysis under socialism, see M. Savelli, 'The peculiar prosperity of psychoanalysis in socialist Yugoslavia', Slavonic and East European Review, 91, 2 (2013), 262-288.

${ }^{5}$ G. Eghigian, 'Was there a communist psychiatry? Politics and East German psychiatric care, 1945-1989', Harvard Review of Psychiatry, 10, 6 (2007), 364-368.

${ }^{6}$ C. Leuenberger, 'Socialist psychotherapy and its dissidents', Journal of the History of the Behavioural Sciences, 37, 3 (2001), 268.

${ }^{7}$ On the history of psychiatry in socialist Eastern Europe, see A. Kiev (ed.), Psychiatry in the Communist World (New York, 1968); M. Savelli and S. Marks (eds), Psychiatry in Communist Europe (Basingstoke, 2015).

${ }^{8}$ D. Herzog, Cold War Freud: psychoanalysis in an age of catastrophes (Cambridge, 2019).

${ }^{9}$ V. Jakovljević, 'Predgovor za knjigu I. Karuza: Drustveni aspekti psihoanalize', in Prilozi sa socijalnu patologiju (Belgrade, 1984), 257-259.

${ }^{10}$ M-J. Calić, Geschichte Jugoslawiens im 20. Jahrhunert (Munich, 2010), 240.

${ }^{11}$ R. Radonjić, Sukob KPJ s Kominternom I drustveni razvoj Jugoslavije, 1948-1950 (Zagreb, 1979), 281.

12 Interview with Dr Nevenka Tadić, 7 February 2014, Belgrade, Serbia; Interview with Dr Dusan Popović, 13 February 2014, Belgrade, Serbia.

13 N. Tadić, Psihijatrija detinjstva i mladosti (Belgrade, 1989 (reprinted)), 18-19.

14 V. Matić, Kada pocinje vaspitanje deteta (Belgrade, 1955), 61-62.

$15 \quad$ Ibid., 62.

16 Kardelj, Borba, 14 January 1950.

17 Tadić, Psihijatrija detinjstva i mladosti, op. cit., 20.

18 V. Jerotić, 'Psihoanaliza, autoanaliza i autonomija licnosti,' Psihoterapija, 2 (1975), 215-217. 
${ }^{19}$ M. Kulenović, 'Izgnanstvo i smrt u tudjem gradu', Psihoterapija, 6:2 (1976), 196.

20 S. Betlheim, 'Kakav je stav lekara prema psihoanalizi’, Nas Vesnik, 204, 3 (1956).

${ }^{21}$ D. Harsch, Revenge of the Domestic: women, the family, and communism in the German Democratic Republic (Princeton, 2007); J. Massino, 'Something old, something new: marital roles and relations in state socialist Romania,' Journal of Women's History, 22:1 (2010), 34-60.

${ }^{22}$ K. Verdery, What Was Socialism, and What Comes Next? (Princeton, NJ, 1996).

${ }^{23}$ S. Penn and J. Massino (eds), Gender Politics and Everyday Life in State Socialist Eastern and Central Europe (Basingstoke, 2009).

${ }^{24}$ H. Scott, Does Socialism Liberate Women? Experiences from Eastern Europe (London, 1974); S. Kruks, R. Rapp and M. B. Young (eds), Promissory Notes: Women in the Transition to Socialism (New York, 1989).

${ }^{25}$ I. Duda, 'Djeca socijalističke domovine. Izgrađivanje pionirske tradicije u Hrvatskoj 1950ih godina' in L. Duraković and A. Matošević (eds), Socijalizam na klupi: Jugoslovensko društvo u očima nove postjugoslovenske humanistike (Pula and Zagreb, 2013), 75-101.

${ }^{26}$ I. Erdei, "'The happy child" as an icon of socialist transformation: Yugoslavia's Pioneer Organization', in J. Lampe and M. Mazower (eds), Ideologies and National Identities: the case of twentieth-century Southeast Europe (Budapest, 2004), 154-179.

27 B. Savić, 'Porodica i drustvo (porodica i vaspitanje dece)' (Belgrade: Izdavacka kuca Rad, 1958), 28.

28 Z. Pesić, 'Sukob starog i novog u braku i porodici' (Belgrade: Izdavacka kuca Rad, 1958), 16-17.

29 Tadić, Psihijatrija detinjstva i mladosti, op. cit., 30.

30 Pesić, op. cit., 25.

31 K. Kondić, Prirucnik za vezbe iz psihopatologije detinjstva I mladosti (Belgrade, 1991 (reprinted)), 18-19.

32 Matić, Mentalna higijena, op. cit. 49.

33 V. Klajn, Ljubav, seks, porodica (Belgrade and Novi Sad, 1981), 242.

${ }^{34}$ Ibid., 240.

35 Ibid., 38-39.

36 Ibid., 32-33. 
37 R.a Galevska, 'Poremecena porodica i deca' (public lecture) (Belgrade: Izdavacka kuca Rad, 1958).

38 Ibid., 36.

${ }^{39}$ N. Tadić, Psihoanaliticka psihoterapija dece i omladine (Belgrade, 1984 (reprinted)), 82.

40 T. Van Rahden, 'Families beyond patriarchy: Visions of gender equality and child rearing among German Catholics in an age of revolution', in N. Christie, M. Gauvreau, and S. Heathron (eds), The Sixties and Beyond: dechristianization as history in North America and Western Europe (Toronto, 2013), 270-93; T. Van Rahden, 'Fatherhood, rechristianization, and the quest for democracy in postwar West Germany', in D.

Schumann (ed.), Raising Citizens in the 'Century of the Child': child-rearing in the United States and German Central Europe in the twentieth century, Studies in German History 12 (New York, 2010), 141-64.

41 D. and Z. Rakić, 'Uloga oca i pseudoseksualizam kao odbrana u klinickoj slici psihoze (prikaz slucaja)', Psihoterapija: Casopis za psihoterapiju i granicna podrucja, 5, 1 (1975), 43-59.

${ }^{42}$ Ibid., 52.

${ }^{43}$ Ibid., 50.

44 Ibid., 55.

${ }^{45}$ V. Matić, 'Zelim da pitam: Briga za brata', TV Novosti, 736, 2 February 1979, 35.

${ }^{46}$ V. Matić, 'Zelim da pitam: Nepoznata bolest, TV Novosti, 742, 16 March 1979.

${ }^{47}$ E., The Romance of American Psychology: political culture in the age of experts (Los Angeles, 1995), 292.

${ }^{48}$ Ibid., 298-299.

${ }^{49}$ Tadić, Psihijatrija detinjstva i mladosti, op. cit.,19.

50 Ibid., 18-19.

51 M. Kramar, 'Prikaz psihoterapije decaka sa govornim smetnjama,' Psihijatrija danas, 1, 2 (1976), 196.

52 Tadić, Psihoanaliticka psihoterapija dece i omladine, op. cit., 66-67.

${ }^{53}$ Ibid., 69-72.

54 Tadić, Psihijatrija detinjstva i mladosti, op. cit., 20-21. 
${ }^{55}$ C. Steiner, 'Radical psychiatry: principles', in The Radical Therapist (New York, 1971), 16-17.

${ }^{56}$ H. Marcuse, Negations: essays in critical theory (Boston, 1967).

${ }^{57}$ Rough Times Collective, 'Introduction', The Radical Therapist (London, 1974), 8-9.

${ }^{58}$ S. Bojanin, Škola kao bolest (Belgrade,1990 (reprinted)), 146.

${ }^{59}$ Ibid.

60 Calic, op. cit., 286-292.

61 Z. Vodovnik, 'Democracy as a verb: new meditations on the Yugoslav Praxis philosophy', Journal of Balkan and Near Eastern Studies, 14, 4 (2012), 433-452.

${ }^{62}$ G. Petrović, 'Cemu praxis?’, Praxis: filozofski casopis, I, 1 (September 1964), 3.

${ }^{63}$ F. Kovacević, 'Marcuse in Yugoslavia', Radical Philosophy Review, 16, 1 (2013), 205-222

${ }^{64}$ D. Pejović, 'Filozofija i psihoanaliza (epilogue)', in H. Marcuse, Eros i civilizacija (Zagreb, 1965), 227.

${ }^{65}$ B. Brujić, 'Moze li se Frojdovom meta-psihologijom utemeljiti povjesnu buducnost', Nase Teme, 6 (June 1966), 1125-1137.

${ }^{66}$ Z. Pešić-Golubović, 'Vladimir Jakovljević (1925-1958)’, 6-7.

${ }^{67}$ B. Jakovljević, Alienation effects: Performance and self-management in Yugoslavia, 19451991 (Ann Arbor, 2016), 120.

${ }^{68}$ Ibid.

69 V. Matić, 'Izmene dinamike odnosa prema autoritetu i njene posledice u klinickoj psihologiji,' Psihologija, 2, 13 (1977), 9.

${ }^{70}$ Ibid.

71 Ibid., 8.

72 Lj. Tadić, 'Moc, elite i demokratija,' Praxis, 1, 2 (1970), 71-72, 74.

73 G. Sher, Praxis: Marxist criticism and dissent in socialist Yugoslavia (Bloomington, London, 1977), 129.

74 Lj. Tadić, Poredak i sloboda (Belgrade, 1976), 76.

75 Ibid., 286.

76 M. Zmuc-Tomori, 'Problemi adolescencije i porodica', Anali Zavoda za mentalno zdravlje, 1 (1974), 171-177. 
77 L. Milcinski, 'Psihiatricni pogledi na narkomanije', Revija za kriminalistiko $i$ kriminalogijo, 3 (1972), 151-157.

78 Tomori, op cit., 177.

${ }^{79}$ B. Kordić, 'Istorija psihoanalize u Srbiji u XX veku', Engrami, 33, 1 (2011).

${ }^{80}$ B. Stojanović, 'Psihoanaliza kao pokret otpora', Danas, 16 October 2012.

81 K. Kondić, Kako sačuvati mentalno zdravlje porodice u izbeglištvu (Belgrade, 2000); T. Stajner-Popović, 'Childhood in a time tunnel', in J. Szekacs-Weisz and I. Ward (eds), Lost Childhood and the Language of Exile (London, 2004); K. Kondić, Priručnik za primenu intervjua s decom lišenom roditeljske pratnje (Belgrade, 1996); V. Ćurčić and V. Brzev Ćurčić, Kako sačuvati mentalno zdravlje mladih u izbeglištvu (Belgrade, 2000).

${ }^{82}$ S. Horvat and I. Stiks (eds), Welcome to the Desert of Post-Socialism: radical politics after Yugoslavia (London, New York, 2015). 